\title{
Review on the major ecosystem impacts caused by damming and watershed development in an Iberian basin (SW-Europe): focus on the Guadiana estuary
}

\author{
P. Morais
}

CIMAR/CCMAR - Centro de Ciências do Mar; Faculdade de Ciências do Mar e do Ambiente, Universidade do Algarve, Campus de Gambelas, 8005-139 Faro, Portugal. Email: pmorais@ualg.pt

\begin{abstract}
The Guadiana estuary (Iberian Peninsula, Europe) has low agriculture, industry and urban pressure, unlike other major Iberian estuaries; however, this situation is about to change. The Alqueva dam was constructed at $150 \mathrm{~km}$ from the river mouth, creating one of the biggest artificial lakes in Europe, which will support 110000 ha of irrigation areas. Moreover, the estuarine margins are suffering increased human pressure. The risks that the Alqueva dam will pose to the downstream ecosystems, mainly to the estuary and adjacent coastal area, will be reviewed in this paper. Other issues are also analysed, as increased human desertification in the Portuguese basin, real estate pressure and the impact of the construction of a public infrastructure in the Portuguese lower estuary. Increased problems of sediment load reduction, water quality deterioration and shifts in the downstream fish populations are expected due to higher river flow reduction. Irreversible changes to estuarine margins and increased risk of pollution in the estuary will result from the multiple urban pressures. Lack of forest management and increased risk of wildfires, leading to water quality degradation and increased soil erosion, are a result of human desertification in the upper Portuguese basin. Multiple solutions to tackle these problems have to be considered. Creating the International Natural Park of the Lower Guadiana would not be enough and tourism should not be regarded as the only way to develop such a poor region. An ecohydrological approach of the basin should be implemented, to establish scientific based solutions to help solving conflicts and testing scenarios. Ultimately, the creation of a Portuguese-Spanish Basin Management Council for the lower Guadiana, involving those that are interested in the sustainable development of the Guadiana (local populations and associations, private stakeholders (dam managers, tourism entrepreneurs, farmers), local and national authorities, ENGO's and scientists) is essential to produce ecological and sustainable management decisions.
\end{abstract}

Keywords: Guadiana basin, dam impacts, Ecohydrology, Alqueva dam, Guadiana estuary

\section{Introduction}

Estuaries are highly dynamic systems, where complex interactions linking physical, chemical, geological and biological components occur, according to tidal amplitude, river flow, episodic events (e.g. floods), local (e.g. rainfall, droughts) and large-scale atmospheric phenomena (e.g. North-Atlantic Oscillation- NAO) and global climate change (Stein et al. 2004, Struyf et al. 2004, Trigo et al. 2004). Estuaries undergo intense anthropogenic impact from urban, agricultural and industrial runoffs along their path, but also from the disturbances that occur in the entire basin (Saiz-Salinas 1997, Grousset et al. 1999, Cearreta et al. 2000, Suzumura et al. 2004), even if located hundreds of kilometres apart. Indeed, damming is one of such disturbances that cause meaningful deleterious changes to downstream ecosystems (Ly 1980, Nixon 2004).
In the Guadiana basin (SW-Iberian Peninsula, Europe) (Fig. 1) the main ecological constraints are damming, water abstraction from aquifers and water pollution. Even so, the estuary is one of the best preserved estuaries of the Iberian Peninsula. Nevertheless, nowadays it has to deal with $i$ ) the impact caused by one of the major European dams, the Alqueva dam, $i i$ ) the creation of 110000 ha of irrigation areas until 2015 in the surroundings of this dam and iii) the destruction of vast natural areas along the estuary margins to build tourist resorts.

One of the solutions to solve or prevent ecological constraints to the estuary should be based on an ecohydrological approach of the ecosystem, i.e. studying the functional inter-relations between hydrology and biota at the catchment scale, in order to propose sustainable water management practises (Zalewski et al. 1997). Successful approaches were already achieved in worldwide 


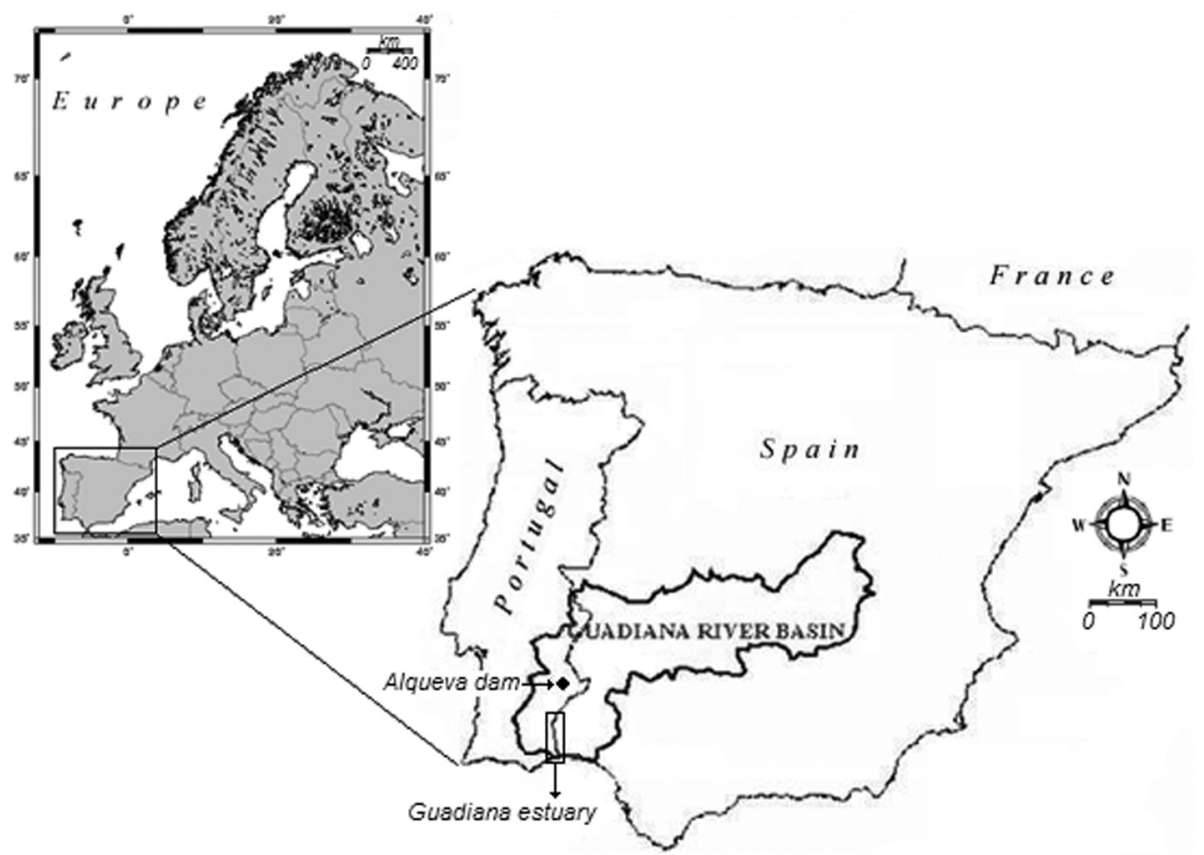

Fig. 1. Geographical location of the Guadiana river basin, Alqueva dam and Guadiana estuary in the Iberian Peninsula (Europe).

freshwater aquatic ecosystems (Hickley et al. 2004, Wagner-Lotkowska et al. 2004, Trepel \& Kieckbusch 2005). Recently, the concept was extended to estuaries and coastal areas (Wolanski et al. 2004); however the concept is being applied in the Guadiana estuary for the past 12 years (Chícharo et al. 2001, Wolanski et al. 2006).

This article will review the main ecological constraints of the Guadiana basin and will focus on the current threats that the Guadiana estuary and the adjacent coastal area has to deal in the present and future (Fig. 2). The impacts caused by damming to these ecosystems will be described, namely those related with sediment load reduction, water quantity and water quality decline and with the impact on fish populations. Preventive and mitigation measures will also be suggested.

\section{The Guadiana basin (SW-Iberian Peninsula, Europe)}

The Guadiana basin is the fourth largest in the Iberian Peninsula and is shared by Portugal and Spain (Fig. 1). The Guadiana river rises in Lagunas de Ruidera (Spain) at an altitude of $1700 \mathrm{~m}$ and drains in the Atlantic Ocean, near the city of Vila Real de Santo António (Portugal). It has an area of $66889 \mathrm{~km}^{2} ; 55364 \mathrm{~km}^{2}$ in Spain and 11525 $\mathrm{km}^{2}$ in Portugal. The river has a total length of $810 \mathrm{~km}$, $550 \mathrm{~km}$ in Spain and $150 \mathrm{~km}$ in Portugal; the remaining forms the border between these countries. The estuary has its tidal limit in Mértola, $70 \mathrm{~km}$ away from the coast. The estuary is mesotidal and tidal amplitudes range from 1.3 to $3.5 \mathrm{~m}$. It occupies an area of $22 \mathrm{~km}^{2}$ and has an average depth of $6.5 \mathrm{~m}$. Annual average temperature varies between 14 and $18{ }^{\circ} \mathrm{C}$. Rainfall is very irregular between years; $80 \%$ is concentrated during autumn and winter, while summers are very dry. Average annual rainfall ranges between 561 and $600 \mathrm{~mm}$ in the Portuguese basin, but high variations are expected between years. River flow has a clear variability between and within years, since the majority of the basin is under the influence of Mediterranean climate. During dry years the average annual river flow oscillates between 8 and $63 \mathrm{~m}^{3} \mathrm{~s}^{-1}$; in a regular year it averages between 170 and $190 \mathrm{~m}^{3} \mathrm{~s}^{-1}$ and between 412 and $463 \mathrm{~m}^{3} \mathrm{~s}^{-1}$ in a humid year (Bettencourt et al. 2003).

There are 1.92 million inhabitants in the entire basin, $88 \%$ of which are in Spain (Euronatura \& IIDMA 2003). Along the estuary, the human presence is sparse and it is mainly located in Portugal. In the low estuary there are two main population agglomerates, Vila Real de Santo António (Portugal) and Ayamonte (Spain), with an approximate resident population of 13880 and 17500 inhabitants, respectively. Direct sources of pollution result from the runoffs and the partly treated or untreated sewages of these cities, of other small villages and of two aquaculture enterprises. Diffusive pollution from agri- 


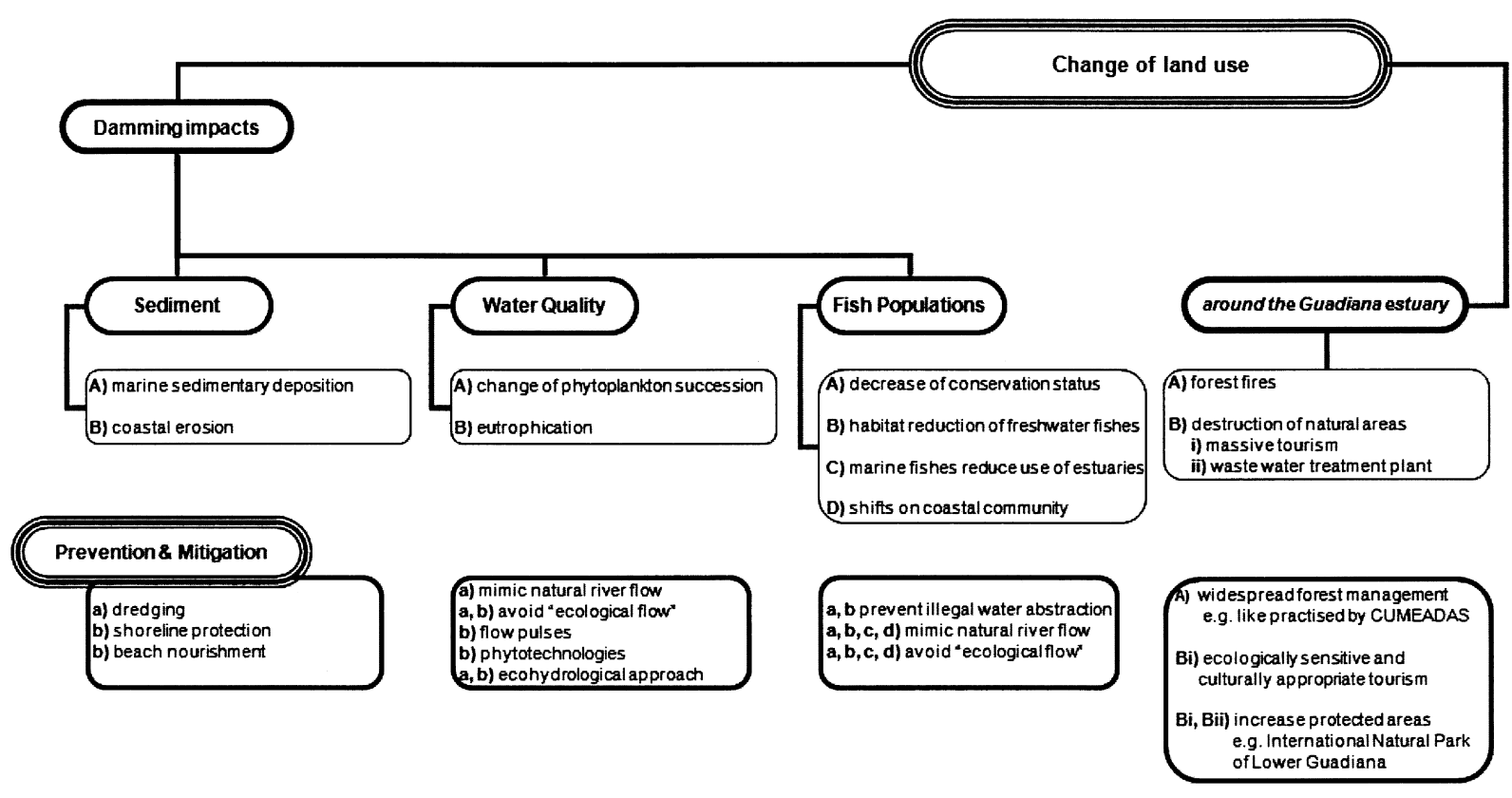

Fig. 2. Main impacts caused by damming and change of land use around the Guadiana estuary and their possible prevention and mitigation measures.

culture, mainly of orange groves in mid estuarine Spanish margins, and from decommissioned mine runoffs in upper estuarine regions also occurs. New tourist resorts are planned for the middle estuary margins and one is almost constructed; therefore they will have to be included in the map of pollution sources. These infrastructures raise huge expectations by the local populations, to improve the local economy, and great concern to regional non-governmental environmental organizations.

There are three ecological constraints in the Guadiana river basin. The first of them is the aquifers overexploitation in the upper basin, which supports extensive irrigation areas. The second ecological constraint is the non-point source pollution originated in these areas and from industries, decommissioned mines, untreated sewages, sewage treatment plants and landfills. The aquifer overexploitation in the upper basin is trying to be mitigated with sustainable water use and with water transfer from the Tagus basin; however this led to the introduction of non-native fish species in the Guadiana basin (Fornés et al. 2000).

The third main ecological constraint of the Guadiana basin is the intense damming. Initially, dams were essential to maintain water supply during the sporadic, but sometimes long drought periods. The first dams of this basin, and also of the Iberian Peninsula, were built by the
Romans in IIA.D. These dams, Cornalvo and Proserpina, had a total capacity of $10 \mathrm{hm}^{3}$ and $4 \mathrm{hm}^{3}$, respectively. Later, several others were built and until 1956, when the Cijara dam $\left(1670 \mathrm{hm}^{3}\right)$ was built, the total amount of water stored in reservoirs was $115 \mathrm{hm}^{3}$. In 1964, this value increased to $3850 \mathrm{hm}^{3}$, increasing slightly until 1988 , when it raised again to $7540 \mathrm{hm}^{3}$ and to $8575 \mathrm{hm}^{3}$ in 1990. Today, after the construction of the Alqueva dam in February $2002,12730 \mathrm{hm}^{3}$ of water can be stored in the 1824 dams of the Guadiana basin. The average total flow of the Guadiana is $4400 \mathrm{hm}^{3}$ (Dias \& Ferreira 2001), however the major 86 dams retain $150 \%$ of the average annual rainfall (UNEP 2006).

The intense damming of the basin raises great concern on water availability, mainly along the Portuguese-Spanish border (Brandão \& Rodrigues 2000). The amount of water drained to the Portuguese basin decreased by about $60 \%$ in the last 30 years and the quality is rather poor. Of the total needs for irrigation and domestic water supply, $81 \%$ and $75 \%$ are consumed and generated in Spain, respectively. The land use is predominantly rural and irrigation accounts for 93\% of water consumption in Spain. Here, non-sustainable agriculture practises cause conflicts between environmental sustainability and socioeconomic interests (Sanz 1999, Fornés et al. 2000).

The impact caused by the construction of the Alqueva dam in the upper Portuguese basin is now the focus of con- 
cern. The Alqueva dam, and the subsidiary Pedrógão dam, will control the river flow before water reaches the estuary, since they are the last in the river main course. The Alqueva dam is located approximately at $150 \mathrm{~km}$ from the river mouth (Figs. 1, 2). It forms at its maximum capacity (152 $\mathrm{m}$ level) one of the biggest artificial lakes in Europe (Hellsten 2003), with an area of $250 \mathrm{~km}^{2}$ (63 km in Spain), a perimeter of approximately $1000 \mathrm{~km}$, a total capacity of $4150 \mathrm{hm}^{3}$ and an useful capacity of $3150 \mathrm{hm}^{3}$. The objectives of the Portuguese government with the construction of the Alqueva dam, and of those that constitute the Alqueva project, were to reinforce the capacity of hydroelectric production, to develop tourism, to promote regional employment, to organize intervention in environmental and patrimony domains, to fight physical desertification and climate change, to modify the agriculture model of south Portugal and to regularize river flow.

\section{Damming and shifts on downstream ecosystems}

Dams were primarily built to supply men of freshwater, either for direct consumption or for agriculture. Later, dams were also built to produce hydroelectric power and to regulate river flow. In many regions, the control of river flow allowed to regulate floods and hence preventing or minimizing there catastrophic effects. However, it often led to the loss of connectivity between rivers and floodplains, which have meaningful negative impacts on aquatic and terrestrial ecosystems, since many plant and animal species can only complete their life cycle if the natural contracting river flow regime is maintained (Bunn \& Arthington 2002). The lower Guadiana basin does not hold a floodplain like many rivers in Europe (e.g. Danube- Central Europe; Loire- France; Tagus-Portugal; Vistula-Poland), only the terminal $5 \mathrm{~km}$ of the river valley has a broader opening, accommodating the extensive salt marshes on both sides of the estuary (Boski et al. 2002). The connectivity between the margins and the Guadiana river/estuary is insufficiently understood (Raposo 2004, R. Santos, Univ. Algarve, unpublished data) and the management of river flow to control eutrophication phenomena in the estuary started just recently (Chícharo et al. 2006a, Morais 2007). Therefore, this chapter will focus on the following consolidated topics: $i$ ) Water quantity and sediment load, $i i$ ) Water quantity and water quality, iii) Water quantity and fish populations.

\section{Water quantity and sediment load}

Damming causes a decline on the quantity of sediment exported to downstream regions, originating deleterious effects on coastal ecosystems, such as coastal erosion and marine sedimentary deposition in the low estuary. However, sediment deposition was also reported, in April 2008, in the fluvial section of the estuary by the city council of Mértola, which blamed the Alqueva dam for this situation (Fig. 2).

Before intensively damming the Guadiana basin, ore exploitation (late $19^{\text {th }}$ and early $20^{\text {th }}$ centuries) and the "wheat campaign" (1938-1945), which occurred in the upper Portuguese basin, increased the sediment transported to the coast. Afterwards, damming had an opposite effect. These contrasting situations drastically changed the area of a sand bank in the river mouth- the O'Brill Bank (Dias et al. 2004). The O'Brill Bank reached its maximum area, $\sim 6 \mathrm{~km}^{2}$ around 1910 , when mining was at its maximum. Mining needed huge amounts of timber, causing deforestation and soil erosion. However, around 1990, after intense basin damming and littoral drift interruption, the O'Brill Bank had an area of $0.7 \mathrm{~km}^{2}$, only $11.6 \%$ of the former maximum area (González et al. 2001).

The Guadiana river mouth was highly dynamic until the construction of two jetties (1972-1974) (Bettencourt et al. 2003), that drastically changed the sediment dynamics (Dias et al. 2004). The western jetty interrupted the predominant eastward littoral drift (Lobo et al. 2002), estimated in $180000 \mathrm{~m}^{3}$.year-1 (González et al. 2001). Nowadays, marine sediment deposition occurs in the river mouth due to $a$ ) the cumulative effect of river flow reduction, $b$ ) the inherent higher flood velocities, $c$ ) the predominant $\mathrm{W}$ and $\mathrm{SW}$ coastal wave regime and $d$ ) the hampering effect on flooding caused by intensive damming (LNEC 2001).

Despite marine sediment accumulation in the river mouth, there is a deficit of supply to the coast. Coastal erosion started in the late 1950's in the Spanish coast (Dias \& Ferreira 2001). The sediment is retained in dams and coastal jetties, which interrupts the predominant eastwards littoral drift (Lobo et al. 2002). The Alqueva dam is expected to amplify coastal erosion (Del Río et al. 2002); however its harshness is unknown. Similar situations are already documented for other Portuguese (Dias et al. 2000, Veloso-Gomes 2002) and worldwide coastal areas (Ly 1980, Palanques et al. 1990, Barusseau et al. 1998, Chen \& Zong 1998).

The predicted sea-level raise will intensify coastal erosion and recession of delta systems (Yang et al.2001) and will cause saltwater penetration into coastal aquifers and estuaries, contaminating urban water supply and affecting agriculture production (Gornitz 1991). To worsen this scenario, the impact of global climate change must 
be considered; indeed it might reduce the current average river discharge up to $60 \%$ (Santos \& Miranda 2006).

\section{Water quantity and water quality}

The water reduction imposed by the Alqueva dam construction, in addition to the impact of all the other dams in the Guadiana basin, will have negative impacts on water quality and on the biological communities of downstream areas (Fig. 2).

The water quality released from young reservoirs can be rather poor, because water with depleted levels of oxygen and high concentrations of hydrogen sulphide is released. These water characteristics result from the decomposition of organic matter in the submerged area of the reservoir (McCully 1996). Clearing the vegetation before submerging a reservoir can reduce the problem. In the Alqueva reservoir, the majority of the vegetation was cleared, but not entirely due to time constraints. The exact area that was not cleared is unknown. There is no available data of the concentrations of dissolved oxygen and hydrogen sulphide that is released from the Alqueva reservoir, but the typical problems associated with these parameters, such as prohibition for consuming water from reservoirs and fauna mortality downstream the dam (McCully 1996), were not observed.

Phytoplankton dynamics have been studied in the upper Guadiana estuary for the last decade (Rocha et al. 2002, Domingues et al. 2005). During the filling of the Alqueva dam (2002-2003), nutrient and phytoplankton dynamics changed drastically (Domingues et al. 2005). Silica concentration increased significantly, however the diatom spring bloom did not occur. Moreover, cyanobacteria abundance increased, not only during summer, as common, but also in autumn and winter.

Long water residence time and water column stability are two of the main leading forces of cyanobacteria dynamics (Paerl 1996, Morais et al. 2003). The higher incidence of cyanobacteria is also associated with degraded ecosystems, mainly in periods of high water and atmospheric temperatures (Hickel 1982, Douterelo et al. 2004). Several cyanobacteria species synthesize toxins (Carmichael 1994, Feuillade 1992), nuisance to aquatic (Pizzolon 1996) and terrestrial communities (Rodas \& Costas 1999). Thus, if dams retain water and diminish river flow, then this process will increase the residence time of downstream water bodies. Water quality is strongly dependent of the water quantity released by dams. This will be critical in periods of consecutive years of droughts, which is not unusual in the Guadiana basin (INAG 2007). Indeed, a long drought period was experienced, in southern Portugal, from 1990 to 1993. The drought, in combination with agricultural (high loads of nitrates, phosphates and pesticides), industrial and urban contamination, caused the blooming of an aquatic fern (Azolla spp.), in vast areas of the Guadiana river. Local and military authorities were involved in its harvest to minimize aquatic eutrophication after the end of Azolla spp. life cycle. This unique event instigated great concern among local populations, in respect to the ecological status of the Guadiana river (Baioa 1997).

\section{Water quantity and fish populations}

Water retention in dams influences not only the fish populations trapped by dams, but also stream fish populations, estuarine ichthyofauna and coastal communities (Fig. 2). The most common impact affecting fish populations that is directly attributed to dams is the obstruction to fish migration (Zhong \& Power 1996) and to the successful reproduction of native fish as consequence of the release of cold waters from dams (McCully 1996). For example, the interruption of salmon migration in the Columbia River caused the loss of 6.5 billion USD in reveneu between 1960-1980, and the Colorado river is now too cold for the successful reproduction of native fish as far as 400 kilometres below the Hoover dam (McCully 1996). In the Guadiana river, there is no study on the impact of the release of cold waters on the successful reproduction of fish, however this relationship was established with native bivalves present downstream of the Alqueva dam (J. Reis, Instituto de Conservação da Natureza, personal communication). Dams also forces fishes to find alternatively migration routes (Antonio et al. 2007), but if a basin is intensively dammed, then there are no alternatively spawning grounds and nursery areas, which severely compromises the conservation status of endemic fishes, like Anaecypris hispanica in the Guadiana basin (Collares-Pereira et al. 1999). The possible construction of more dams in the lower stretches of the Guadiana basin will clearly compromise the integrity of this species. Moreover, it is often accepted that dams are genetic barriers, disabling gene flow between populations located upstream and downstream dams. This statement can not be generalized, because it can be true for some species (Neraas \& Spruell 2001), but not for others (Reid et al.2008), even for different species inhabit in the same dam (Haponski et al. 2007).

More negative impacts on ichthyofauna occurred in southern Portuguese reservoirs, in Alentejo and Algarve. In July 2005, 170 tonnes of fish had to be collected from reservoirs during a drought period with the influence of a heat wave, in order to avoid fish death in the reservoirs and the consequent deterioration of water quality. 
The significant reduction of river flow decreases the amount of sediments transported to the coast and hence the extent of the estuarine plume, an important migration cue for fish, either during their larval or adult stages. Thus, the abundance of marine fishes that use the estuary as a spawning ground or as a nursery area decreases (Drinkwater \& Frank 1994, Kingsford \& Suthers 1994). The reduction of river flow also causes the reduction of freshwater fish habitat, namely of barbells- Barbus comiza, Barbusmicrocephalus, Barbus sclateri and Barbus steindachneri (Chícharo et al. 2006b). These species are endemic to Iberian southern freshwater ecosystems and classified as threatened (SNPRCN 1991). Other brackish and freshwater species, such as allis shad (Alosa alosa) and twaite shad (Alosa fallax), have a vulnerable status, meaning that they will be in danger if the limiting factors, over-fishing and general habitat destruction, continue to exist (IUCN 2001).

Five fish species present in the streams of the lower Guadiana are listed in the Annex II of Habitats Directive: lamprey (Petromyzon marinus), several cyprinidae (Rutilus alburnoides, Cobitis maroccana and A. hispanica) and sturgeon (Acipenser sturio). As mentioned, $A$. hispanica is an endemism of the Guadiana streams and is in threat of extinction (Collares-Pereira \& Cowx 2001). The conservation status of $A$. hispanica changed drastically in few years, from abundant to threatened with extinction (Collares-Pereira et al. 1999, Salgueiro et al. 2003). Damming and water abstraction for irrigation explain this change, once it destroys or damages the habitat, interferes with reproduction opportunities, may generate polluted effluents and facilitate the introduction of non-native competitor species (Collares-Pereira et al. 2000). Acipenser sturio is extirpated from this basin; since the early 1980's that no sturgeon is caught (Almaça \& Elvira 2000).

Damming can also be the cause for coastal fisheries decline. The most representative example was the construction of the Aswan High Dam (Nile River- Egypt) in 1964. After its construction, the river flow reduction caused a decline of more than $90 \%$ in the nutrients exported to the coastal area, which led to the collapse of coastal fisheries. Fisheries recovered in the mid 1980's, due to a tremendous increase of nutrient inputs from agriculture fertilizers and sewage outfalls (Nixon 2003, 2004). Indeed, river flow was also the factor that better explained the Guadiana coastal fisheries shifts; among sea surface temperature, rainfall, upwelling, NAO, number of licensed fishing vessels and number of commercial fishermen (Erzini 2005). In the years following significant changes of river flow, the structure of coastal community also shifts. In dry years, the landings of planktivorous fish, such as sardine and anchovy, are significantly lower. Between years of high and low inflow, sardine landings decreased, in average, $69 \%$, from 886 to 279 tonnes; while landings of carnivorous fish (e.g. white sea-bream, axillary sea-bream, red sea-bream and red-porgy) increased between $112 \%$ and $128 \%$ (Chícharo et al. 2003).

In the coastal area adjacent to the Ebre River (Spain), anchovy landings were positively related with river flow during its reproduction period (Lloret et al. 2004). In the coastal area adjacent to the Gironde estuary (France), river flow explained the shifts in anchovy larval condition and recruitment (Bergeron 2004). In the Guadiana estuary, there was a one year time lag between meaningful changes of river flow and an effect on fish captures (Chícharo et al. 2003, Erzini 2005). The same conclusion was expressed for the Adriatic Sea (Marasović 1990) and Nile (Nixon, 2003, 2004). In the Adriatic sea, increasing sardine captures were related to increasing productivity, resulting of higher eutrophication originated by the Po River (Italy) outflow. Indeed, river flow acts as a "coastal fertilizer".

\section{Change of land use around the Guadiana estuary}

The Guadiana estuary has low agriculture, industry and urban pressure, in comparison to the most important Iberian estuaries (Tagus, Douro, Guadalquivir and Ebre estuaries) (Solé et al. 2000, Silva et al. 2004, Ferreira et al. 2004, Riba et al. 2004). Currently, this situation is about to change, not only due to the activities that occur in the distant Alqueva dam and upstream areas, but also in the surrounding estuarine areas. Here, the occurrence of forest fires and destruction of vast natural areas are now the main threats to the ecological balance of the estuary (Fig. 2).

In the upper Guadiana estuary, intense mining and agriculture have caused water contamination and deterioration (Bettencourt et al. 2003). Nowadays, ecosystem degradation can result from the lack of land use and management, a consequence of demographic regression in Portugal and Spain (Euronatura \& IIDMA 2003). The majority of the Portuguese Guadiana river basin overlaps with some of the poorest regions of the European Union, forcing the youngsters to find work in more prosperous regions. The increase of local populations' age and the decrease of manpower committed to maintain forests in proper conditions lead to an increase of the probability for the occurrence of forest fires. Wildfires increase the risk of soil nutrient depletion and erosion (Townsend \& Douglas 2000, Shakesby et al. 2003); consequently, water quality decrease (Rab 1996, Townsend \& Douglas 
2004), mainly in streams, small rivers and water reservoirs. Even so, wildfires' negative impacts might be buffered in bigger aquatic ecosystems (Cornish \& Binns 1987), namely by the estuary.

In the middle estuary, the construction of an enormous tourist resort in Spain (north of Ayamonte), and of others that are approved for the Portuguese margin (near Almada de Ouro and Castro Marim), will destroy vast natural areas and dramatically change others. The construction of the Spanish tourist resort is being finished (Figs. 3, 4). It will host 20000 inhabitants, lodged in 6000 houses and in 3 luxury hotels, and equipped with 7 shopping centres, 2 golf courts and 1 marina, which undoubtedly represents a tremendous change on land and estuary use. It is located in a site without previous human pressure, near the northern limit of the Natural Reserve of Castro Marim and Vila Real de Santo António. Moreover, it is in the vicinity of an important estuarine area for the development of several resident and migratory fish species, such as eels (Anguilla anguilla), meagres (Argyrosomus regius), temperate basses (Dicentrarchus spp.), gilt head sea breams (Sparus aurata) and common soles (Solea vulgaris). The degree of heavy metal contamination in the trophic web of the Guadiana estuary is practically unknown (Ferreira 1994). In the sediment, a higher degree of trace metals contamination are found near the marinas, shipyards and water runoffs of Vila Real de Santo António and Ayamonte and from orange fields in the middle estuary. However, the worst cases of pollution are classified as low polluted, in opposition to the adjacent heavy polluted estuaries- Carreras, Piedras and Tinto-Odiel estuaries (Ruiz 2001). But with these infrastructures the threat of pollution increases, as well as its dissemination and bioaccumulation along the food web.

In the low estuary, a sewage treatment plant, with tertiary treatment, will be built outside Vila Real de Santo António (Portugal) to fulfil the requirements of the residual water discharge legislation (Fig. 3). This station will treat sewages that are currently discharged untreated to the environment and replace several sewage treatment plants with inappropriate functioning (Altura, Manta Rota and Castro Marim) (PROCESL 2001). This is, undoubtedly, an important environmental achievement, since it will reduce the amount of organic matter, nutrients and microbial pathogens to the environment; however it will be located in Rato salt marsh. This salt marsh is $6 \mathrm{~km}$ from the estuary mouth and at the entrance of two creeks, "Esteiro da Carrasqueira" and "Esteiro da Lezíria", in the Natural Reserve of Castro Marim and Vila Real de Santo António, an area of high terrestrial and estuarine biodiversity. This Natural Reserve is classified as a Zone of Special Protec-

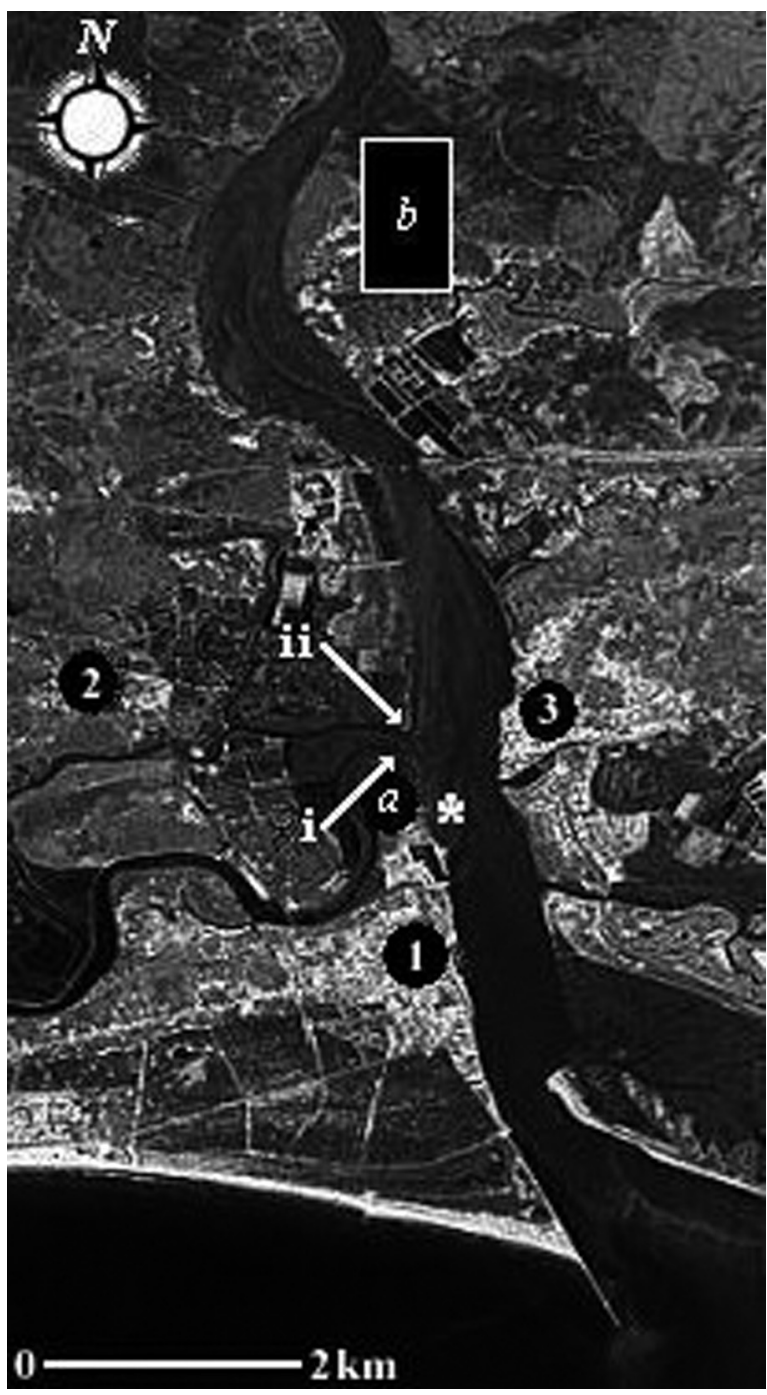

Fig. 3. Aerial photograph of the lower section of the Guadiana estuary. Legend: 1- Vila Real de Santo António; 2- Castro Marim; 3- Ayamonte; a- Rato saltmarsh; b- tourist resort; i- Carrasqueira creek; ii- Lezíria creek; *- possible location for water sewage treatment outflow. Photograph modified from http:// mapmachine.nationalgeographic.com

tion (PTZPE0018), a humid area of international importance (RAMSAR site- 7PT010), an area of special protection for birds (directive 79/409/EEC), a region under the jurisdiction of Habitats Directive (92/43/EEC) and inscribed in the Natura 2000 network (PTCON0013). The construction of the sewage treatment plant will destroy 12 ha of the salt marsh. This area is a protected habitat by the Annex I of Habitats Directive (habitats 1410, 1420 and 1430) and the impact on flora is meaningful and irreversible. Rato salt marsh has the most important area of 


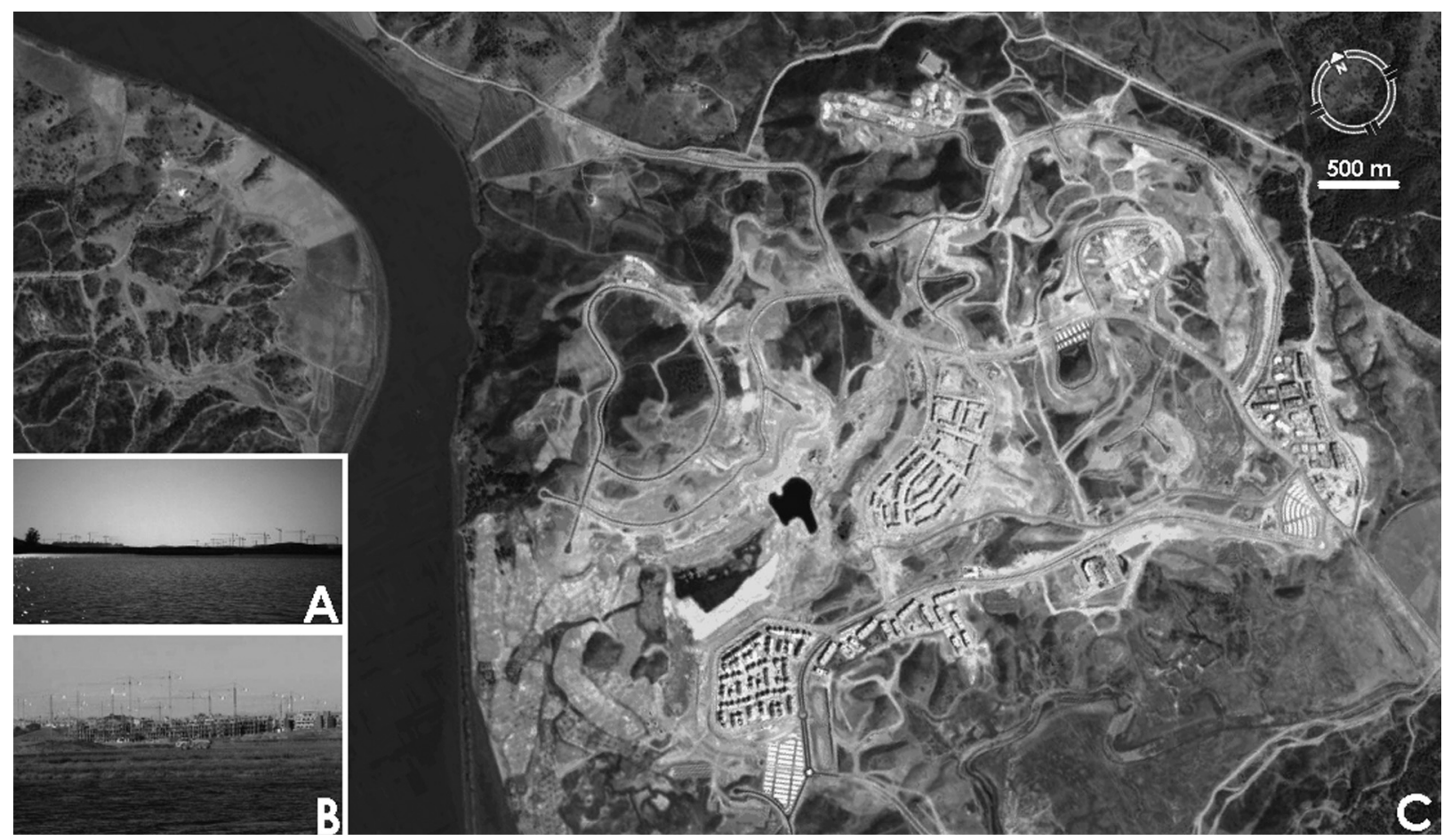

Fig. 4. Photographs of a tourist resort that is being constructed in the Spanish lower Guadiana estuary. Fig. 4C was modified from Google Earth.

primary salt marsh of the natural reserve and the more diverse bird population (Dias 1999). In fact, the Portuguese Society for the Study of Birds and BirdLife International, two important NGO's, recognized that this Natural Reserve is extremely important for several nidifying birds, winter migrants and in obligatory passage. This salt marsh area is vital for several steppe species, such as thick-knees (Burhinus oedicnemus), calandra lark (Melanocorypha calandra), little bustard (Tetrax tetrax), and to lesser short-toed lark (Calandrella rufescens). This species has in this area the only nesting location in Portugal (Leitão 2003). The salt marsh is also a nesting place for two birds of prey, western marsh-harrier (Circus aeruginosus) and Montagu's harrier (Circus pygargus) (Leitão 2003). The intertidal areas adjacent to the sewage treatment plant are feeding grounds for nine limnic species, ruddy turnstone (Arenaria interpres), dunlin (Calidris alpina), curlew sandpiper (Calidris ferruginea), Kentish plover (Charadrius alexandrinus), common ringed plover (Charadrius hiaticula), black-tailed godwit (Limosa limosa), grey plover (Pluvialis squatarola), little tern (Sterna albifrons) and common redshank (Tringa teta$n u s)$; some of which are included in the Annex I of Bird Directive (Dias 1999, Dias et al. 2003). The sewage treatment plant will impact a vital estuarine area for the reproduction and growth of ichthyofauna, during their larval
(Faria et al. 2006), juvenile and adult life stages (Bexiga 2002, Chícharo et al. 2006b). Some of the species have high economical value, like black sea bream (Spondyliosoma cantharus), gilt-head sea bream (Sparus aurata), sea breams (Diplodus spp.), temperate basses (Dicentrarchus spp.) and Senegal sole (Solea senegalensis). The sewage outflow will be located $250 \mathrm{~m}$ off "Esteiro da Carrasqueira" creek (Fig. 3), in order to protect these creeks of singular ecological sensibility, of great importance to aquatic life and to salt production. This way, the pollutants released into the estuary will be transported to distant places from the creeks during the flood (PROCESL 2001). Nevertheless, this estuarine area and the areas upstream are extremely important for ichthyofauna. Food chain contamination and bioaccumulation (Polprasert 1982) should have been considered, since sewage treatment plants can be a major point source of heavy metal contamination on aquatic ecosystems and biota (Al-Jundi 2000). Therefore, redirecting the sewage treatment outflow to the estuary does not eliminate the threats to creeks' biota.

\section{Prevention and mitigation}

The preventive and mitigation measures that scientists propose can only be effectively achieved if the knowledge that they possess is clearly transmitted to the 


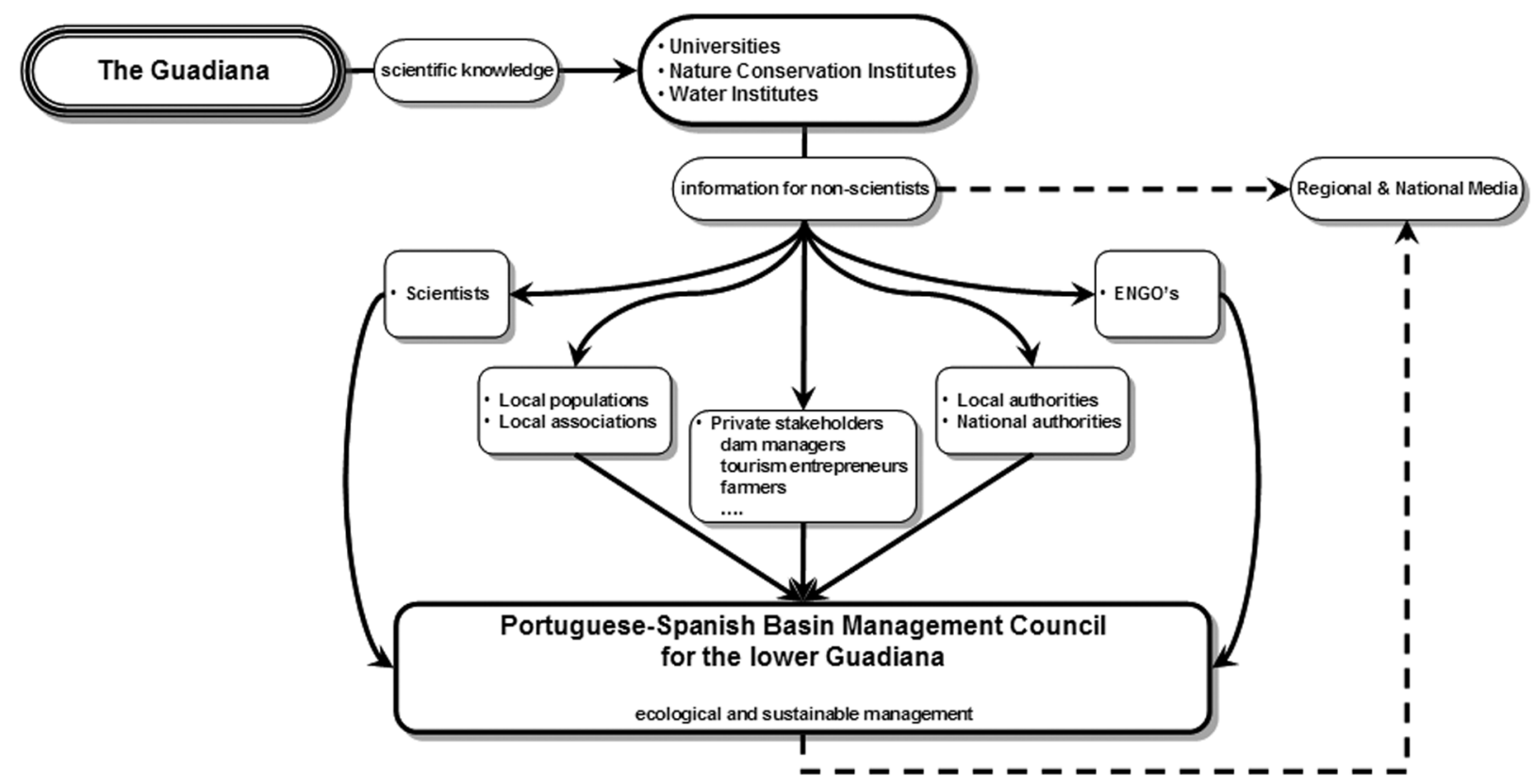

Fig. 5. Proposed inputs to the decision-making process of a Portuguese-Spanish basin management council for the lower Guadiana.

non-scientific community interested in the sustainable development of the Guadiana, e.g. local populations and associations, private stakeholders (dam managers, tourism entrepreneurs, farmers), local and national authorities, ENGO's (Environmental non-governmental organizations) and other scientists (Fig. 5). The creation of a Portuguese-Spanish Basin Management Council for the lower Guadiana, bringing together the mentioned partners, would be essential to produce ecological and sustainable management decisions. A connection with local and national media would be crucial to raise the aware of populations to the local environmental issues.

The problems caused by the reduction of sediment transported to the coast can only be solved with expensive engineering works, namely beach nourishment and ultimately shoreline protection. The inhibition of floods results in marine sedimentary deposition in the river mouth, solved only with dredging.

In basins where river flow is greatly controlled by dams, the natural river flow is drastically altered. In these places, there is a time lag between maximum rainfall and maximum river discharge. This delay can sometimes compromise the recruitment of estuarine fish species; this way mimicking natural river flow regime could help preventing some negative impacts on fish populations (Loneragan \& Bunn 1999) and shifts on the natural patterns of other biological communities. It is in this sense that "ecological flows" should be avoided for long periods.
Dam managers can control or mitigate eutrophication phenomena in the downstream areas of the Alqueva dam by setting flow pulses. Thus, secondary production would be promoted and primary producers' biomass controlled. This is achieved when the magnitude and periodicity of hydraulic flushing and nutrient loading are large (Maier et al. 2001, Roelke et al. 2003). Even so, the intensity and length of hydraulic flushing have to be site specific and should take into account the impact on estuarine fish populations. The conservation status of freshwater fishes, as well as native bivalves, is threatened by the illegal water abstraction from streams, mainly during summer. Therefore, this practise should continue to be prevented by the local authorities.

The questions regarding ecosystem balance can only be answered with robust ecosystem modelling, only achieved after a long lasting ecohydrological approach to the ecosystem. Such questions could be $i$ ) "Will the Guadiana coastal fisheries decrease sharply as happened in the coastal area of the Nile, after the construction of the Aswan High dam?", ii) "What will be the impact of the 110000 ha of Alqueva irrigation complex on the water quality of aquifers and in all the downstream areas, mainly during periods of reduced river flow?" and iii) "Will the nutrients used in the Alqueva irrigation complex be the trigger that stimulate an increment in coastal productivity and inherently on coastal fisheries?". One of the major benefits of an ecohydrological approach is that it allows weighting the benefits and risks of the multiple 
water uses (e.g. damming, irrigation, human consumption, electrical production).

If phytotechnology solutions would be implemented in the Alqueva irrigation complex it would be possible $i$ ) to augment resilience and capacity of natural systems to absorb impacts, ii) to prevent and control pollutant release and environment degradation, or even iii) to remediate and restore degraded ecosystems and contaminated sites (Zalewski \& Wagner-Lotkowska 2004). This is possible because riparian wetlands, and also saltmarshes, help to regulate hydrology, sedimentation, nutrient status and sequestrate pollutants.

The occurrence of forest fires is part of a complex socio-economical context as previously described. The preventive measures of forest management proposed by a local association of forest owners- CUMEADAS (Association of Forest Owners of Cumeadas of Lower Guadiana), should be broadly implemented. There goals are $a$ ) to protect the forest by implementing a global management plan, $b$ ) to prevent and fight forest fires and to recover such areas, $c$ ) to develop and promote sustainable agriculture practices in an area that now faces severe problems of desertification, $d$ ) to recover ancient but effective agriculture procedures, $e$ ) to develop rural tourism and $f$ ) to promote environmental education among the local populations.

Finally, the destruction of vast natural areas around the Guadiana estuary is of great concern to ENGO's (e.g. Almargem), as some of these areas are inscribed in Natura 2000 network (site PTCON0036). One of their proposals is to create a Biosphere Reserve or the International Natural Park of the Lower Guadiana, in order to resist/stop the development of massive tourism projects, as occur in the littoral areas of southern Portugal and Spain. It would also serve to compensate the loss of biological diversity that the construction of the Alqueva dam forced.

Sometimes, it is difficult to make a compromise between effective nature conservation and economical improvement of such a poor area. Positive impacts in local economy should be achieved with sustainable and rational growth of human activities in the area, including tourism. Tourism is regarded as the solution to achieve economic development in southern Portugal. However, the achievement of economically viable tourism in this region has to be ecologically sensitive and culturally appropriate (Wall 1997). Therefore, nature protection and understanding the worth of the high natural patrimony that characterize the lower Guadiana would not be neglected nor forgotten.

\section{Conclusions}

The conflicts and constraints on the use of Guadiana water and land exist along its entire path, posing multiple management difficulties. To achieve a social development of the lower Guadiana basin, with sustainable environmental decisions, is a tremendous endeavour. It has to rely on solid scientific input, on the commitment of basin managers, on the determination of local and regional authorities, on the active involvement of ENGO's, on the awareness of populations and will of private entrepreneurs, which could be enhanced by a Portuguese-Spanish basin management council.

The creation of the International Natural Park of the Lower Guadiana would not resolve the conflict "nature protection" versus "water demand and dam impacts", even though it would be needed to avoid the destruction of vast natural areas of great ecological relevance. But it could allow achieving the sustainable development of such a poor region with environmental sensitive tourism projects.

A huge step-forward for a balanced basin management would result from the implementation of a multidisciplinary study of the Guadiana basin. The scientifically based proposals would help solving conflicts and testing management scenarios; but, for that, long lasting monitoring programs and an ecohydrological approach are compulsory.

\section{Acknowledgment}

The fruitful discussions with Ana Faria, Ester Dias, Joaquim Teodósio, Marta Freitas, Paula Mendonça, Rita Domingues, Ronaldo Sousa and Susana Cabaço on a preliminary version of this manuscript were very important to achieve this final version, as well as the comments made by two anonymous reviewers. The author was supported by $\mathrm{PhD}$ and Post-Doc grants from "Fundação para a Ciência e a Tecnologia" (SFRH/BD/5187/2001; SFRM/BDP/ 40832/2007).

\section{References}

Al-Jundi J. 2000. - Determination of trace elements and heavy metals in the Zarka River sediments by instrumental neutron activation analysis. Nuc. Instruments Methods Phys. Res. B, 170, 180-186.

Almaça C. \& Elvira B. 2000. - Past and present distribution of Acipenser sturio L., 1758 on the Iberian Peninsula. Boletín Instituto Español de Oceanografia, 16, 11-16.

António R.R., Agostinho A.A., Pelicice F.M., Bailly D., Okada E.K. \& Dias J.H.P. 2007. - Blockage of migration routes by dam construction: can migratory fish find alternative routes? Neotrop. Ichthyol., 5, 177-184.

Baioa M.V. 1997. - Impacte ambiental do "bloom" de Azolla no concelho de Mértola, M.Sc. Thesis, Univ. Évora, Évora.

Barusseau J.P., Bâ M., Descamps C., Diop E.S., Diouf B., Kane A., Saos J.L. \& Soumaré A. 1998. - Morphological and sedimentological changes in the Senegal River estuary after the constuction of the Diama dam. J. Afr. Earth Sci., 26, 317-326. 
Bergeron, J.-P. 2004. - Contrasting years in the Gironde estuary (Bay of Biscay, NE Atlantic) springtime outflow and consequences for zooplankton pyruvate kinase activity and the nutritional condition of anchovy larvae: an early view. ICES $J$. Mar. Sci., 61, 928-932.

Bettencourt A., Gomes V., Dias J.A., Ferreira G., Silva M.C. \& Costa L. 2003. - Estuários Portugueses. Instituto da Água, Lisboa, $300 \mathrm{p}$.

Bexiga C. 2002. - Comunidade ictiológica estuarina do Guadiana e sapal de Castro Marim, M.Sc. Thesis, Univer. Algarve, Faro.

Boski T., Moura D., Veiga-Pires C., Camacho S., Duarte D., Scott D.B. \& Fernandes S.G. 2002. - Postglacial sea-level rise and sedimentary response in the Guadiana Estuary, Portugal/Spain border. Sediment. Geol., 150, 103-122.

Brandão C. \& Rodrigues R. 2000. - Hydrological simulation of the international catchment of Guadiana River. Phys. Chem. Earth (B), 25, 329-339.

Bunn S.E. \& Arthington A.H. 2002. - Basic principles and ecological consequences of altered flow regimes for aquatic biodiversity. Environ. Manage., 4, 492-507.

Carmichael W.W. 1994. - The toxins of cyanobacteria. Sci. Am., $270,7886$.

Cearreta A., Irabien M.J., Leorri E., Yusta I., Croudace I.W. \& Cundy A.B. 2000. - Recent anthropogenic impacts on the Bilbao Estuary, northern Spain: geochemical and microfaunal evidence. Est. Coast. Shelf Sci., 50, 571-592.

Chen X. \& Zong Y. 1998. - Coastal erosion along the Changjiang deltaic shoreline, China: history and prospective. Est. Coast. Shelf Sci., 46, 733-742.

Chícharo L., Chícharo M.A. \& Ben-Hamadou R. 2006a. - Use of a hydrotechnical infrastructure (Alqueva Dam) to regulate planktonic assemblages in the Guadiana estuary: Basis for sustainable water and ecosystem services management. Est. Coast. Shelf Sci., 70, 3-18.

Chícharo L., Chícharo M.A. \& Morais P. 2003. - Effects of Guadiana river inflow on coastal fisheries. Thalassas, 19, 99-100.

Chícharo M.A., Chícharo L. \& Morais P. 2006b. - Influence of freshwater inflow changes on the ichthyofauna of Guadiana estuary and adjacent coastal area (SE-Portugal/SW-Spain). Est. Coast. Shelf Sci., 70, 39-51.

Chícharo M.A., Chícharo L.M., Galvão H., Barbosa A., Marques M.H., Andrade J.P., Esteves E., Miguel C. \& Gouveia I. 2001. Status of the Guadiana estuary (South Portugal) during 1996-1998: an ecohydrological approach. Aquat. Ecosyst. Health Manage., 4, 73-90.

Collares-Pereira M.J. \& Cowx I.G. 2001. - Threatened fishes of the world: Anaecypris hispanica (Steindachner, 1866). Environ. Biol. Fish., 60, 410.

Collares-Pereira M.J., Cowx I.G., Rodrigues J.A., Rogado L. \& da Costa L.M. 1999. - The status of Anaecypris hispanica in Portugal: problems of conserving a highly endangered Iberian species. Biol. Conserv., 88, 207-212.

Collares-Pereira M.J., Cowx I.G., Ribeiro F., Rodrigues J.A. \& Rogado L. 2000. - Threats imposed by water resource development schemes on the conservation of endangered fish species in the Guadiana River Basin in Portugal. Fish. Manage. Ecol., 7, 167-178.

Cornish P.M. \& Binns D. 1987. - Streamwater quality following logging and wildfire in a dry sclerophyll forest in southeastern Australia. For. Ecol. Manage., 22, 1-28.

Del Río L., Benavente J., Garcia F.J., Infuso G., Martínez-del-Pozo J.A., Domínguez L., Rodríguez-Ramírez A., Flores E., Cáceres L., López-Aguayo F. \& Rodríguez-Vidal J. 2002. - The quantification of coastal erosion processes in the South Atlantic
Spanish coast: methodology and preliminary results. Littoral, 2, 383-390.

Dias J.A. \& Ferreira Ó. 2001. - Estudo Multidisciplinar do Estuário do Rio Guadiana. CIACOMAR, Olhão, 150 p.

Dias J.M.A., González R. \& Ferreira Ó. 2004. - Natural versus anthropic causes in variations of sand export from river basins: An example from the Guadiana river mouth (southwestern Iberia). Pol. Geol. Inst., 11, 95-102.

Dias J.M.A., Boski T., Rodrigues A. \& Magalhães F. 2000. - Coast line evolution in Portugal since the Last Glacial Maximum until present - a synthesis. Mar. Geol., 170, 177-186.

Dias M. 1999. - Aves aquáticas das salinas de Castro Marim. Fenologia, utilização do habitat, prioridades de conservação e propostas de gestão, Degree Thesis, Univ. Lisboa, Lisboa.

Dias M.P., Lecoq M. \& Rabaça J.E. 2003. - Comunidade de aves dos sapais secos dos estuários do Tejo e do Guadiana. Pages 59-61 in Seminário sobre a conservação da avifauna dos sapais secos da Reserva Natural de Castro Marim e Vila Real de Santo António. ICN (eds). ICN, Lisboa.

Domingues R.B., Barbosa A. \& Galvão H. 2005. - Nutrients, light and phytoplankton succession in a temperate estuary (the Guadiana, south-western Iberia). Est. Coast. Shelf Sci., 64, 249-260.

Douterelo I., Perona E. \& Mateo P. 2004. - Use of cyanobacteria to assess water quality in running waters. Environ . Pollut., 127, 377-384.

Drinkwater K.F. \& Frank K.T. 1994. - Effects of river regulation and diversion on marine fish and invertebrates. Aquat. Conserv., 4, 135-151.

Erzini K. 2005. - Trends in NE Atlantic landings (southern Portugal): identifying the relative importance of fisheries and environmental variables. Fish. Oceanogr., 14, 195-209.

Euronatura \& IIDMA 2003. - Aplicação da directiva-quadro da água e Convenção Luso-Espanhola de 1998 na Bacia Hidrográfica do Guadiana. Euronatura, Lisboa, 44 p.

Faria A., Morais P. \& Chícharo M.A. 2006. - Icthyoplankton dynamics in the Guadiana and adjacent coastal area (SE-Portugal/SW-Spain). Est. Coast. Shelf Sci., 70, 85-97.

Ferreira C. 1994. - Determinação dos níveis de Cd. Fe e Mn nos tecidos de mexilhões, Mytilus galloprovincialis (Lamarck, 1819), provenientes do estuário do Rio Guadiana, Degree Thesis, Univ. Algarve, Faro.

Ferreira M., Antunes P., Gil O., Vale C. \& Reis-Henriques M.A. 2004. - Organochlorine contaminants in flounder (Platichthys flesus) and mullet (Mugil cephalus) from Douro estuary, and their use as sentinel species for environmental monitoring. Aquat. Toxicol., 69, 347-357.

Feuillade J. 1992. - Les toxines des cyanobactéries: revue de synthèse. Rev. Sci. Eau, 5, 489-508.

Fornés J., Rodríguez J.A., Hernández N. \& Llamas M.R. 2000. Possible solutions to avoid conflicts between water resources development and wetland conservation in the "La Mancha Húmeda" biosphere reserve (Spain). Phys. Chem. Earth (B), 25, 623-627.

González R., Dias J.A. \& Ferreira Ó. 2001. - Recent rapid evolution of the Guadiana estuary mouth (Southwestern Iberian Peninsula). J. Coast. Res., 34, 516-527.

Gornitz V. 1991. - Global coastal hazards from future sea level rise. Global Planet. Change, 3, 379-398.

Grousset F.E., Jouanneau J.M., Castaing P., Lavaux G. \& Latouche C. 1999. - A 70 year record of contamination from industrial activity along the Garonne River and its tributaries (SW France). Est. Coast. Shelf Sci., 48, 401-414.

Hellsten S. 2003. - Letter to the Editor. SIL News, 40, 8. 
Hickel B. 1982. - A helical, bloom-forming Anabaena-like blue-green alga (Cyanophyta) from hypertrophic lakes. Arch. Hydrobiologia, 95, 115-124.

Hickley P., Arlinghaus R., Tyner R., Aprahamian M., Parry K. \& Carter M. 2004. - Rehabilitation of urban lake fisheries for angling by managing habitat: General overview and case studies from England and Wales. Ecohydrol. Hydrobiol., 4, 365-378.

Haponski A.E., Marth T.A. \& Stepien C.A. 2007. - Genetic divergence across a low-head dam: A preliminary analysis using logperch and greenside darters. J. Gt. Lakes Res., 33, 117-126.

INAG (Instituto Nacional da Água) 2007. - Webedition < http:// www.inag.pt $>$.

IUCN (The World Conservation Union) 2001. - IUCN Red List Categories and Criteria: Version 3.1. Gland and Cambridge: IUCN Species Survival Commission, Gland \& Cambridge, 38 p.

Leitão D. 2003. - Estratégia para a conservação da avifauna dos sapais secos da Reserva Natural do sapa de Castro Marim e de Vila Real de Santo António. SPEA, Lisboa, 77 p.

Lloret J., Palomera I., Salat J. \& Sole I. 2004. - Impact of freshwater input and wind on landings of anchovy (Engraulis encrasicolus) and sardine (Sardina pilchardus) in shelf waters surrounding the Ebre (Ebro) River delta (north-western Mediterranean). Fish. Oceanogr., 13, 102-110.

LNEC (Laboratório Nacional de Engenharia Civil) 2001. - Estudo das condições ambientais no estuário do Rio Guadiana e zonas adjacentes. LNEC, Lisboa, p.

Lobo F.J., Hernández-Molina J., Somoza L., Diáz del Rio V. \& Dias J.M.A. 2002. - Stratigraphic evidence of an upper Pleistocene TST to HST complex on the Gulf of Cádiz continental shelf (south-west Iberian Peninsula). Geo-Mar. Lett., 22, 95-107.

Loneragan N.R. \& Bunn S.E. 1999. - River flow and estuarine ecosystems: Implication for coastal fisheries from a review and a case study of Logan River, southeast Queensland. Aust. J. Ecol., 24, 431-440.

Ly C.K. 1980. - The role of the Akosombo Dam on the Volta river in causing coastal erosion in central and eastern Ghana (West Africa). Mar. Geol., 37, 323-332.

Maier H.R., Burch M.D. \& Bormans M. 2001. - Flow management strategies to control blooms of the cyanobacterium Anabaena circinalis in the River Murray at Morgan, South Australia. Regul. Rivers: Res. Manage., 17, 637-650.

Marasović I. 1990. - Phytoplankton productivity of the Adriatic Sea in relation to the fishing grounds. Perspect. Phycol., 247-255.

McCully P. 1996. - Silence rivers: the ecology and politics of large dams. Zed Books, London, $352 \mathrm{p}$.

Morais P. 2007. - The life cycle of Engraulis encrasicolus sensu lato in the Guadiana estuary: ecology, ecohydrology and biology, Ph.D. Thesis, Univ. Algarve, Faro.

Morais P., Chícharo M.A. \& Barbosa A. 2003. - Phytoplankton dynamics in a coastal saline lake (SE-Portugal). Acta Oecol., 24, S87-S96.

Neraas L.P. \& Spruell, P. 2001. - Fragmentation of riverine systems: the genetic effects of dams on bull trout (Salvelinus confluentus) in the Clark Fork River system. Mol. Ecol., 10, 1153-1164.

Nixon S.W. 2003. - Replacing the Nile: are anthropogenic nutrients providing the fertility once brought to the Mediterranean by a great river? Ambio, 32, 30-39.

Nixon S.W. 2004. - The artificial Nile. Am. Sci., 92, 158-165.

Paerl H.W. 1996. - A comparison of cyanobacterial bloom dynamics in freshwater, estuarine and marine environments. Phycologia, 26, 25-35.

Palanques A., Plana F. \& Maldonado A. 1990. - Recent influence of man on the Ebro margin sedimentation system, northwestern Mediterranean Sea. Mar. Geol., 95, 247-263.
Pizzolon L. 1996. - Importancia de las cianobacterias como factor de toxicidad en las aguas continentales. Interciencia, 21, 239-245.

Polprasert C. 1982. - Heavy metal pollution in the Chao Phraya River estuary, Thailand. Water Res., 16, 775-784.

PROCESL (Engenharia Hidráulica e Ambiental, Lda.) 2001. - ETAR de Vila Real de Santo António. Projecto de execução. Estudo de impacto ambiental, resumo não técnico. PROCESL, Vila Real de Santo António, 15 p.

Rab M.A. 1996. - Soil physical and hydrological properties following logging and slash burning in the Eucalyptus regnuns forest of southeastern Australia. For. Ecol. Manage., 84, 159-176.

Raposo, V. 2004. - Caracterização da teia trófica do sapal de Castro Marim e interacção com o Estuário do rio Guadiana, Degree Thesis, Univ. Algarve, Faro.

Reid S.M., Wilson C.C., Mandrak N.E. \& Carl L.M. 2008. Population structure and genetic diversity of black redhorse (Moxostoma duquesnei) in a highly fragmented watershed. Conserv. Genet., 9, 531-546.

Riba I., de Canales M.G., Forja J.M. \& DelValls T.A. 2004. Sediment quality in the Guadalquivir estuary: sublethal effects associated with the Aznalcóllar mining spill. Mar. Pollut. Bull., 48, 153-163.

Rocha C., Galvão H. \& Barbosa A. 2002. - Role of transient silicon limitation in the development of cyanobacteria blooms in the Guadiana estuary, south-western Iberia. Mar. Ecol. Progr. Ser., $228,35-45$.

Rodas V.L. \& Costas E. 1999. - Preference of mice to consume Microcystis aeruginosa (toxin-producing cyanobacteria): A possible explanation for numerous fatalities of livestock and wildlife. Res. Vet. Sci., 67, 107-110.

Roelke D., Augustine S. \& Buyukates Y. 2003. - Directing the fall of Darwin's "Grain in the balance": Manipulation of hydraulic flushing as a potential control of phytoplankton dynamics. Tex. Water Resour. Inst., 245, 1-13.

Ruiz F. 2001. - Trace metals in estuarine sediments from the southwestern Spanish coast. Mar. Pollut. Bull., 42, 482-490.

Saiz-Salinas J.I. 1997. - Evaluation of adverse biological effects induced by pollution in the Bilbao Estuary (Spain). Environ. Pollut., 96, 351-359.

Salgueiro P., Carvalho G., Collares-Pereira M.J. \& Coelho M.M. 2003. - Microsatellite analysis of genetic population structure of the endangered cyprinid Anaecypris hispanica in Portugal: implications for conservation. Biol. Conserv., 109, 47-56.

Santos F.D. \& Miranda P. 2006. - Alterações climáticas em Portugal: cenários, impactos e medidas de adaptação. Gradiva, Lisboa, $506 \mathrm{p}$.

Sanz G.L. 1999. - Irrigated agriculture in the Guadiana River high basin (Castilla-La Mancha, Spain): environmental and socioeconomic impacts. Agric. Water Manage., 40, 171-181.

Shakesby R.A., Chafer C.J., Doerr S.H., Blake W.H., Wallbrink P., Humphreys, G.S. \& Harrington, B.A. 2003. - Fire severity, water repellency characteristics and hydrogeomorphological changes following the Christmas 2001 Sydney forest fires. Aust. Geographer, 34, 147-175.

Silva S., Ré A., Pestana P., Rodrigues A. \& Quintino V. 2004. Sediment disturbance off the Tagus Estuary, Western Portugal: chronic contamination, sewage outfall operation and runoff events. Mar. Pollut. Bull., 49, 154-162.

SNPRCN (Serviço Nacional de Parques, Reservas e Conservação da Natureza) 1991. - Peixes dulçaquícolas e migradores. Livro vermelho dos vertebrados de Portugal. Secretaria de Estado dos Recursos Naturais, Lisboa, 55 p. 
Solé M., Porte C., Barcelo D. \& Albaiges J. 2000. - Bivalves residue analysis for the assessment of coastal pollution in the Ebro Delta (NW Mediterranean). Mar. Pollut. Bull., 40, 746-753.

Stein R., Dittmers K., Fahl K., Kraus M., Matthiessen J., Niessen F., Pirrung M., Polyakova Ye., Schoster F., Steinke T. \& Fütterer D.K. 2004. - Arctic (palaeo) river discharge and environmental change: evidence from the Holocene Kara Sea sedimentary record. Quat. Sci. Rev., 23, 1485-1511.

Struyf E., Van Damme S. \& Meire P. 2004. - Possible effects of climate change on estuarine nutrient fluxes: a case study in the highly nutrified Schelde estuary (Belgium, The Netherlands). Est. Coast. Shelf Sci., 60, 649-661.

Suzumura M., Kokubun H. \& Arata N. 2004. - Distribution and characteristics of suspended particulate matter in a heavily eutrophic estuary, Tokyo Bay, Japan. Mar. Poll. Bull., 49, 496-503.

Townsend S.A. \& Douglas M.M. 2000. - The effect of three fire regimes on stream water quality, water yield and export coefficients in a tropical savanna (northern Australia). J. Hydrol., 229, 118-137.

Townsend S.A. \& Douglas M.M. 2004. - The effect of a wildfire on stream water quality and catchment water yield in a tropical savanna excluded from fire for 10 years (Kakadu National Park, North Australia). Water Res., 38, 3051-3058.

Trepel M. \& Kieckbusch J.J. 2005. - Influence of macrophytes on river water levels and flood dynamics in the Upper Eider river valley a riparian wetland in Northern Germany. Ecohydrol. Hydrobiol., 5, 23-32.

Trigo R.M., Vázques D.P., Osborn T.J., Castro-Díez Y., Gámiz-Fortis S. \& Esteban-Parra M.J. 2004. - North Atlantic Oscillation influence on precipitation, river flow and water resources in the Iberian Peninsula. Int. J. Climatol., 24, 925-944.
UNEP 2006. - Webedition < http://www.grid.unep.ch >

Veloso-Gomes F., Taveira-Pinto F., Barbosa J.P., das Neves L. \& Coelho C. 2002. - High risk situation in the NW Portuguese coast: Douro River-Cape Mondego. Littoral, 2, 411-422.

Wagner-Lotkowska I., Bocian J., Pypaert P., Santiago-Fandino V., \& Zalewski M. 2004. - Environment and economy- Dual benefit of ecohydrology and phytotechnology in water resources management: Pilica River Demonstration Project under the auspices of UNESCO and UNEP. Ecohydrol. Hydrobiol., 4, 345-352.

Wall G. 1997. - Is ecotourism sustainable? Environ. Manage., 21, 483-491.

Wolanski E., Boorman L.A., Chícharo L., Langlois-Saliou E., Lara R., Plater R.A.J., Uncles R.J., \& Zalewski M. 2004. Ecohydrology as a new tool for sustainable management of estuaries and coastal waters. Wetlands Ecol. Manage., 12, 235-276.

Wolanski E., Chícharo L., Chícharo M.A. \& Morais P. 2006. - An ecohydrology model of the Guadiana Estuary (South Portugal). Est. Coast. Shelf Sci., 70, 132-143.

Yang S.-L., Ding P.-X. \& Chen S.-L. 2001. - Changes in progradation rate of the tidal flats at the mouth of the Changjiang (Yangtze) River, China. Geomorphology, 38, 167-180.

Zalewski M., Janauer G.A. \& Jolánkai G. 1997. - Ecohydrology- a new paradigm for the sustainable use of aquatic resources. UNESCO, Paris, $58 \mathrm{p}$.

Zalewski M. \& Wagner-Lotkowska I. 2004. - Integrated watershed management- Ecohydrology \& Phytotechnologies. UNEP UNESCO-IHP, Osaka, 246 p.

Zhong Y. \& Power G. 1996. - Environmental impacts of hydroelectric projects on fish resources in China. Regul. Rivers Res. Manage., 12, 81-98. 
